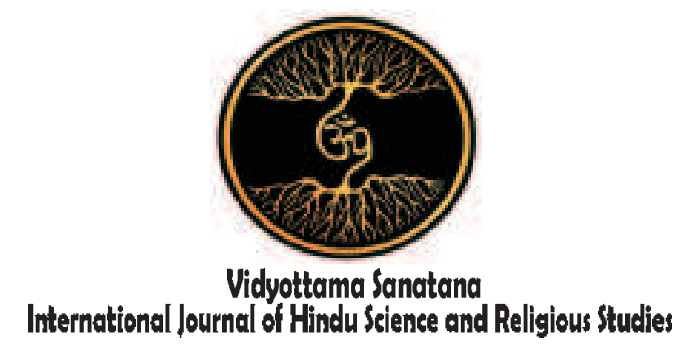

Vol. 1 No. 2 October 2017

\title{
The Phenomena of Plagiarism in Hindu Perspective
}

\author{
By: \\ I Dewa Gede Rat Dwiyana Putra \\ Institut Hindu Dharma Negeri Denpasar \\ Email: ratdwiyanaputra@gmail.com
}

\begin{tabular}{|l|l|l|}
\hline Received: August 22, 2017 & Accepted: September 15, 2017 & Published: October 30, 2017 \\
\hline
\end{tabular}

\begin{abstract}
This article was made based on an observation on the thesis written by undergraduate student. The basic reason for the application of this research is that, there were many problem found in the students writing especially the in the citation process and referencing technique which would bring them to commit plagiarism. Since writing a thesis is essential for the undergraduate students to finish their study, this research would be very beneficial evidence to give a clear picture about plagiarism from Hindus teaching perspective. Library research is the primary method applied in conducting this research. The result shows that there are typical mistakes done by the students in doing citation and referencing. Then, suggestions to those problems were given based on Hindus perspective.
\end{abstract}

Key words: Plagiarism, Thesis, Undergraduate Students

\section{Introduction}

Writing is one of the four basic skills of language. It is considered as the aural product of language from an unlimited planning, editing and revision (Bailey in Nunan, 2003, p. 48). People produce a writing based on their selfknowledge or other sources and it is aimed to a specific purpose. One of the most important purposes in writing is academic purpose. For example, undergraduate students will treat an academic writing as prominent requirement to accomplish their purpose because thesis is a long piece of writing as a part of university degree (Oxford, 2004). Therefore an undergraduate student needs to do a careful planning and repetitive editing and revision for their thesis which requires a lot of time to be accomplished.

However, the process of writing is not always smooth. There are a lot of problems faced by the students before a final writing assignment is ready to be submitted. The first 
common problem faced by the students is the time given in finishing the writing is often very limited. In finishing a final thesis for the undergraduate students, the timeline of the writing process tart from proposal building, proposal exam, data collection, analysis and the process of supervision done in a very limited time. The second problem is, lack of sources, where students could not find the source easily because of the limitation of knowledge about where to find the source. Students are familiar to the library as the source of the books of references but coming to library is hard for them. Finding sources in the internet is also an alternative, but their ability in choosing the eligible sources is still questionable. The last problem is the task difficulty, Students with a burden of limited time and limited sources are burdened by a high demand of the teacher or lecturer. So, when the students are intimidated by those problems, they tend to constitute plagiarism. According to Carroll in Dawson and Overfield (2006),

'Plagiarism is defined as passing off someone else's work, whether intentionally or unintentionally, as your own for your own benefits'

In other word it can be said that the students serve the unoriginal idea for their task. What makes it unoriginal is the absence of the sources. Writer would underline this statement that the absence of the sources is not merely they are intended to do plagiarism but it might be because of the lack of knowledge of how to do it correctly. It means that the students may unintentionally plagiarize the idea from a book or other writing product. Then in order to confirm this idea, this research was conducted.

Based on the background of study above, writer then narrow the research problem into three main questions, those are;

1. What is the definition and categories of Plagiarism?
2. What is the student's problem in academic writing?

3. What are the example phenomena of plagiarism in the thesis written by undergraduate students?

4. How is the phenomenon of plagiarism seen from Hindus perspective?

5. What recommendation could be given based on Hindus perspective?

The general purpose of this research is to detect the phenomena of plagiarism in the thesis written by undergraduate students. The detailed objectives of this paper are:

1. To discuss the definition and categories of Plagiarism.

2. To identify the student's problem in academic writing.

3. To detect the phenomena of plagiarism in the thesis written by undergraduate students.

4. To describe the phenomenon of plagiarism seen from Hindus perspective

5. To give recommendation based on Hindus perspective.

The method applied in this research is library research, where the writer observes the thesis written by the undergraduate students in the library.

\section{Discussion}

\subsection{Plagiarism phenomenon; Definition}

Jones (2011) states that plagiarism is belong to "Academic Dishonesty" together with "cheating" and "fraud". People who guilty of plagiarism are the same as theft of ideas. They use another people words or ideas in their own writing without acknowledging the real author. In the reference section, they also omit the source information as like as the ideas are their own.

Carroll in Dawson and Overfield (2006) also infers that plagiarism can be said as morally 
wrong and it is a kind of collusion. It means that when plagiarizers submit or present their product of writing, they are lying to the audience. In a same case also they are not performing their own knowledge but only stealing from other ideas. In this case, plagiarizers do double immoral activities at the same time. Besides, when two people work together to produce a writing, but at the end they submit the writing individually, they also guilty of plagiarism. From those statements we can clearly understand that when plagiarizing an idea, work or words from someone, plagiarizers pretend that those things stolen are belong to their own although the one where they steal from is their classmates.

\subsection{Student's problems in thesis writing}

Since thesis determines the study accomplishment of undergraduate students, they will do any effort to finish it. But some problems also take role in the process of thesis writing. According to Miller (2010), there are some problems encountered by the students in thesis writing. First, students sometime choose a broad topic which makes the writing too long or too much or they are trapped in a narrow topic which makes the writing too short. This can be happened both because the students have low understanding on the topic given by the teacher and the teacher has failed delivering the topic coverage that should be accomplished by students. Second, students may lose the flow of arguments and ideas because of the failure in connecting thesis statement and the body of the thesis. Lack of writing practice might fall to this result. Students easily do copy-paste information from various sources without adjusting it into their flow of ideas. Besides, students who have lack of evidence and sources which support their arguments will direct them to a shallow writing. Poor formatting also becomes the vital problem encountered in writing thesis since in every university the formatting and style is different in which most of the students have lack knowledge. In relation with the formatting, students find that it is difficult during referencing and making citations in their thesis. Improper citations and references in a thesis will constitute plagiarism. It means that, if both of the teacher and students were able to understand the rules in writing especially referencing, plagiarism would be prevented.

From those statements we can clearly identify that the most prominent reason of plagiarism is the lack knowledge of writing style, especially in citation, quotation, and referencing in a correct formatting.

\subsection{Plagiarism phenomenon; Categories}

There are many categories of plagiarism. Every expert has his own differentiation of plagiarism categories. Jones (2011) clearly divides plagiarism into four main category, those are:

1. Unauthorized and/or unacknowledged collaborative work.

2. Using the whole or a part of another person, group or institution's work and attempt to pass them off, as a personal work. This kind of plagiarism can also be divided into four sub categories, those are;

a. Using such material without any attribution, citation, acknowledgment and quotation marks.

b. The use of such material with the use of false, deceptive or fabricated citations.

c. The use of such material with quotation marks but without any or with false attribution and citation.

d. The use of such material which is correctly attributed and properly cited, but without quotation marks.

3. The use of any amount of text that has been improperly paraphrased constitutes plagiarism. This kind of plagiarism is also called "mosaic plagiarism" or "cut-andpaste plagiarism."

4. The use of any amount of text, that is 
properly paraphrased, but it is either not cited or improperly cited.

From those categories of plagiarism, the main point indicated plagiarism is "acknowledgement" which considers quoting technique and punctuation and referencing style. This statement matches the problem encountered by the students in which they experience difficulties in understanding rules in writing, especially referencing. In this paper writer also presents the detection example of this phenomenon.

\subsection{Plagiarism phenomenon; Detection from the thesis written by undergraduate students}

In this section, writer provided a clear detection example of plagiarism from a thesis written by undergraduate students. The detections will focused in improper quoting technique and punctuation and referencing style according to the consideration gathered from the previous sub topic "Plagiarism phenomenon; Categories”.

There are two major types of quoting technique. Those are direct quotation and indirect quotation (paraphrasing, summarizing and synthesizing). When we need to use the exact word from other expert to be used in our project work, we can use direct quotation. A short direct quotation can be in line with the text while a long direct quotation should be written in a separated paragraph and the quotation mark is omitted. Besides, when we only need the idea of other writer, we can paraphrase, summarize or synthesize the words into our own word to keep the flow of our ideas. Note that all of those kind of quoting techniques need a proper referencing Svobodova, Z., et al. (2000).

Figure 1 shows the example of the improper quoting technique and punctuation found in one of a thesis written by undergraduate student.

Figure 1. Part of the thesis written by undergraduate students (Tari, 2011, p. 6)

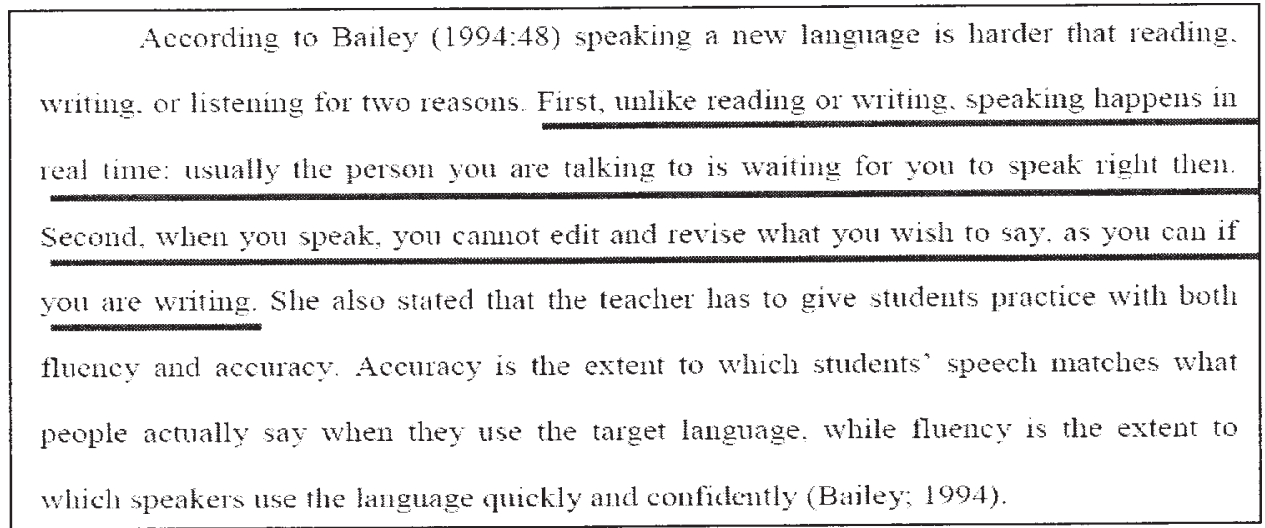

Figure 2. Source Text (Bailey in Nunan, 2003, p. 48)

\section{What is speaking?}

If you have learned a language other than your own, which of the four skills-listening, speaking, reading, or writing-did you find to be the hardest? Many people feel that speaking in a new language is harder than reading, writing, or listening for two reasuns. First, unlike reading or writing, speaking hap pens in real time: usually the person you are taking to is waiting for you to speak right then. Second, when you speak, you camnot edit and revise what you wish to say, as you can 11 you ate wming.

In language teaching, the four skills are described in lerms of their direc- 
Figure 3. Correction 1

Speaking is the most difficult language skill to be mastered by the students. Bailey in Nunan (2003) states two reasons why speaking is harder than other language skills;

First, unlike reading or writing, speaking happens in real time: usually the person you are talking to is waiting for you to speak right then. Second, when you speak, you cannot edit and revise what you wish to say, as you can if you are writing. (Bailey in Nunan, 2003, p. 48)

From the figures above we can see that part of thesis written used exactly the same word as the source text. This is considered as the direct quotation and since the quotation is up to three lines, it should be written in separated paragraph. The correct quotation for the thesis should be as follows;

The in-text reference showed in Figure 1 is "Bailey (1994:48)". But there is no clear sources appear in the reference section as shown by figure 4 .
The source text is the book titled "Practical English Language Teaching" Edited by David Nunan in which several writers give their contribution for the book including Kathleen M. Bailey who give her contribution in chapter 3, "Speaking". So, in the reference section it should be written:

Figures above give us a factual example which describe that the improper citation done by the undergraduate student in her thesis is in a very basic of quotation rules including

Figure 4. Reference section (Tari, 2011)

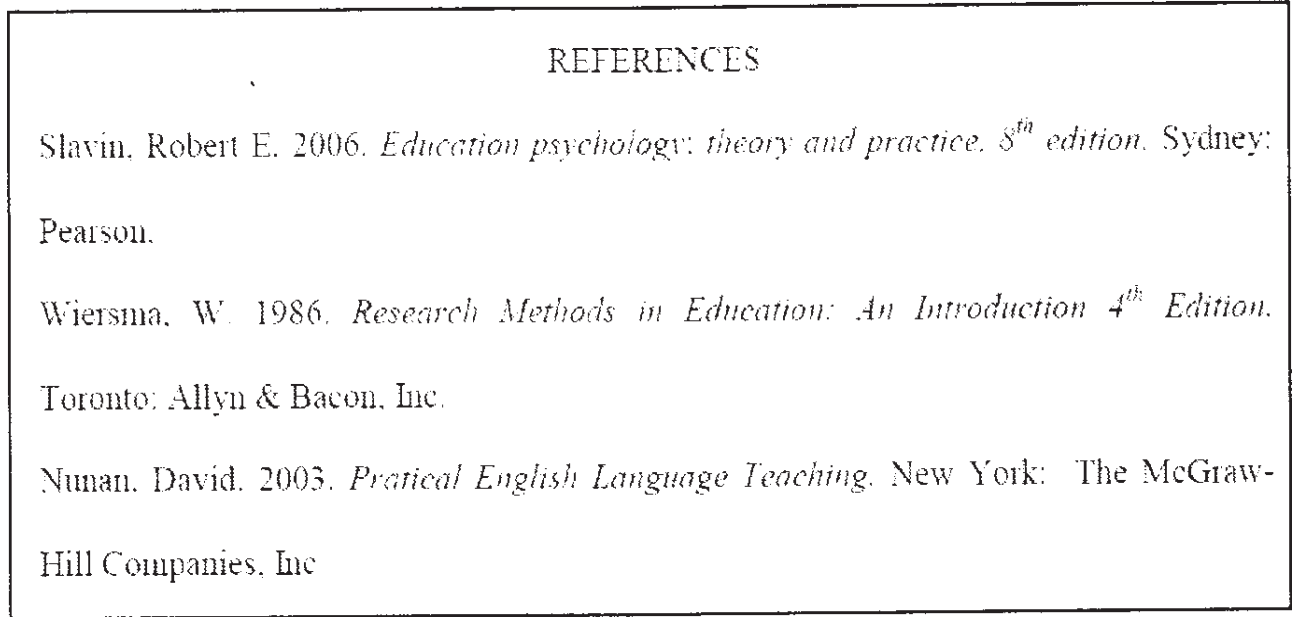

Figure 5. Correction 2

Bailey, K.M. (2003). Speaking. In Nunan, D. (Ed.), Practical English Language Teaching, (International ed., pp. 47-66). Singapore: McGraw-Hill. 
technique, formatting and referencing style. The student is guilty of plagiarism based on those evidences.

The evidences detected show that the mistakes done in several basic points. First, the thesis writer copied word per word from the source text to her work. Although she already put in-text reference, she used improper text formatting for the long direct quotation which must be written in separated paragraph. Second, the written in-text reference is inappropriate with the real source. Source text is taken from a book edited by David Nunan, but she wrote "Bailey (1994:48)". Actually, Kathleen M. Bailey is one of the contributors of the book. This also counted as improper formatting of in-text reference. Last, the reference section also incorrect. Bailey as the one who has the idea is not written, while Nunan who is only the editor of the book is written as if the whole book is his own. The thesis writer shows a lack understanding of reference formatting since the references is not in alphabetical order.

All of the evidences found deal with the improper formatting of quotation, punctuation and reference section. The thesis writer already knows "what to do" but she does not know how to do it in a correct way". This is in line with the prominent problem found by the students, which is having lack knowledge of writing style, especially in citation, quotation, and referencing in a correct formatting. It can be inferred that the thesis writer has a low knowledge of rules in writing a scientific writing.

There are several ways to solve this proven problem. Actually it can be prevented by giving the students a clear understanding about the rules of writing, especially in referencing technique. The students can be given lots of writing practice for the preparation of their thesis writing. The teacher also has to state a clear explanation of topic coverage and the regulation.

\subsection{Plagiarism phenomenon; Hindus Perspectives}

The phenomenon of plagiarism violates at least two general Hindus teaching. The first violated Hindus teaching is the teaching of "Tri Kaya Parisudha”. Rosalina, (2017:223) mentioned that Tri Kaya Parisudha is comprised of three main concept, namely the purity of 'mind' (Manacika), 'utterance' (Wacika) and 'attitude' (Kayika)), that able to promote an intellectual, emotional, spiritual and creative energies. Students in higher education in any field of study is expected to be able to implement this three concept in their learning activity especially in producing the final assignment in form of thesis, because this product would reflect how is the quantity and the quality of the graduate students. The high quantity students means that they are able internalize as much as possible the content of study the followed during college. The quality of students illustrates the synchronization of the content knowledge (cognitive), character (affective) and skill (psychomotor) they apply in their product.

The second violation is done to the teaching of "Panca Satya". In Hinduism there are five kinds of "satya" faithfullness concept, that are often called the "Panca Satya". There are five concepts of "Panca Satya", namely; 1) Satya Hredaya is the faithfulness of mind, 2) Satya Wacana is the faithfulness of utterance, 3) Satya Semaya is the faithfulness of the promise, 4) Satya Mitra is the faithfulness of friendship, and 5) Satya Laksana is faithfulness to the deed (Wijaya, 1981: 115 in Suprabi, 2015: 5). The students who commit plagiarism violate the teaching of Satya Laksana, because what they write on the academic product or thesis could not be accounted for its truth, because the ideas written on the thesis might belong to others which is not referred or cited properly. 
2.6 Recommendation to Overcome Plagiarism Based on Hindus Perspectives

Based on the evidences above, it is clear that there are still many plagiarism practice done by the students. This phenomenon brings out many disadvantages for both the students and the institution where they study. Therefore, based on Hindus teaching there would be several recommendations that could be done to solve this problem, namely;

1. Undergraduate students, especially those who believe in Hindus should be given a clear understanding of the application of both "Tri Kaya Parisudha" and "Panca Satya" teaching in their learning activity especially in thesis writing.

2. Thesis writing guidelines, especially in Hindus higher education should include the teaching of "Tri Kaya Parisudha" and "Panca Satya" as the philosophy of thesis writing. Therefore, the students would have a better and stronger base of attitude in academic writing.

3. The supervising and evaluation system should be improved to avoid these plagiarism phenomena. Therefore, both the students and the institution would be free from being accused from plagiarism.

\section{Conclusion}

A scientific writing, especially research report or thesis is prestigious types of writing. Students have to be aware of the rules regulating it. Since most of the students have difficulties in formatting rules, lots of improper formatting found in undergraduate student's thesis, those are, improper quoting technique, improper intext reference formatting and improper reference section formatting. Therefore, undergraduate students have to search more knowledge of the formatting rules used in their institution before produce writing, otherwise improper writing will constitutes plagiarism which will make the students suffer from institutional penalties. Besides the teacher has to be able to give a clear explanation of the task coverage and it is suggested to give the students sources where they can cite the additional information and how should they cite them properly.

\section{References}

Bailey, K.M. (2003). Speaking. In Nunan, D. (Ed.), Practical English Language Teaching,

(International ed., pp. 47-66). Singapore: McGraw-Hill.

Carroll, J. (2002). In Dawson, M. M. \& Overfield, J. A. (2006). Plagiarism: Do Students Know What It Is?. Bioscience Education Journal, 8, 1. Retrieved September 16, 2012 from http:// www.bioscience.heacademy.ac.uk/beej8-1.pdf

Jones, L. R. (2011). Academic Integrity \& Academic Dishonesty: A Handbook about Cheating \& Plagiarism (Revised \& Expanded ed. p. 5). Retrieved September 16, 2012 from http:// www.fit.edu/current/documents/ plagiarism.pdf

Miller, C. (2010, October 19). Problems Encountered in Writing a Science Paper. Retrieved September 16, 2012 from http:/ $/ w w w . a r t i c l e s b a s e . c o m / c o l l e g e-a n d-$ university-articles/problemsencountered-in-writing-a-sciencepaper-3502351.html

Svobodova, Z., Katzorke, H., Jaekel, U., Dugovicova, S., Scoggin, M., Treacher, P. (2000). Writing in English: A Practical Handbook for Scientific and Technical Writer. Retrieved September 16, 2012 from http://rcum.uni-mb.si/fkkt/Stud/ files/Writing_in_English.pdf 
Rosalina, P.D. 2017. The Implementation of Hindu Philosophy “Tri Kaya Parisudha” for Sustainable Tourism in Munduk Village, North Bali. Jurnal Master Pariwisata, 3 (2). pp. 223-237. Denpasar: Universitas Udayana: From https://ojs.unud.ac.id/ index.php/jumpa/article/view/28451/ 17774

Suprabi, C.I.A. 2015. Teks Geguritan Dalem Tarukan : Analisis Struktur Dan Nilai. Jurnal Fakultas Ilmu Budaya Universitas Udayana: HUMANIS, 12, (3). pp. 1-8. Denpasar: Universitas Udayana. From https://ojs.unud.ac.id/ index.php/sastra/article/view/ 15581
Tari, N. (2011). The Effect of Using "Speaking Random Club" Technique toward the Students' Speaking Competency of the Ninth Grade Students in SMP N 3 Sawan in the Academic Year of 2010/2011. (Unpublished undergraduate thesis).Undiksha University of Education, Singaraja.

Thesis. (2003). Oxford Learner's Pocket Dictionary (New ed., p. 448). China: Oxford University Press. 